\title{
PRODUCTION AND PARTIAL CHARACTERIZATION OF A MILK-CLOTTING PROTEINASE PRODUCED BY BACILLUS SUBTILIS SMDFS-2B MN715837 IN SUBMERGED CULTURES
}

\author{
Jermen Mamo ${ }^{1,2 *}$, Martin Kangwa ${ }^{3}$, Hector Marcelo Fernandez-Lahore ${ }^{3}$, Fassil Assefa $^{l}$ \\ Address (es): \\ ${ }^{1}$ Microbial, Cellular and Molecular Biology Department, Addis Ababa University, Addis Ababa, Ethiopia. \\ ${ }^{2}$ Department of Biology, College of Natural and Computational Science, Debre Berhan University, Debre Berhan, Ethiopia. \\ ${ }^{3}$ Downstream Processing Laboratory, Department of Life Sciences and Chemistry, Jacobs University, Bremen, Germany. \\ *Corresponding author: jermenmamo@yahoo.com or jermanmamo@dbu.edu.et

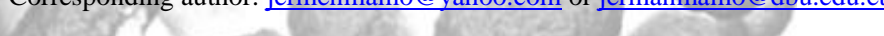 \\ ABSTRACT
}

https://doi.org/10.36547/be.257

This study focused on the production and partial characterization of a milk-clotting protease produced by Bacillus subtilis SMDFS 2B in submerged cultures, under partially optimized conditions. The crude enzyme was recovered in the culture supernatant and concentrate was produced after cell removal and subsequent dialysis. Inhibition studies were conducted employing four distinct protease inhibitors: Pepstatin-A, Phenylmethane-sulphonyl-fluoride (PMSF), Ethylenediaminetetraacetic acid (EDTA), and iodoacetamide (IA). The effect of temperature, $\mathrm{pH}$, metal ions and substrate concentration on milk-clotting activity were also evaluated. The thermal stability of the enzyme was determined by incubating the crude enzyme at a temperature value ranging from $35{ }^{\circ} \mathrm{C}$ to $60{ }^{\circ} \mathrm{C}$. Similarly, pH stability was determined at $\mathrm{pH}$ values ranging between 4.5 and 8.0. The highest milk-clotting activity was observed at a temperature of $55^{\circ} \mathrm{C}$ and $\mathrm{pH} 5.5$. The crude enzyme preparation remained stable on incubation at $35{ }^{\circ} \mathrm{C}$ and $40{ }^{\circ} \mathrm{C}$ for $15 \mathrm{~min}$ and at $\mathrm{pH} 5.5$. The enzyme also showed the lowest residual milk-clotting activity in the presence of EDTA (7.94\%) and Pepstatin-A (26.71\%). The addition of $\mathrm{Mg}^{2+}$ and $\mathrm{Mn}^{2+}$ significantly increased milk-clotting activity. The enzyme also showed an elevation in its apparent milkclotting activity upon increasing the substrate (skim-milk) concentration. Thus, the milk-clotting protease produced by $B$. subtilis SMDFS $2 \mathrm{~B}$ by submerged fermentation revealed some interesting milk-clotting characteristics. This may open the way for applications in the food and dairy industries.

Keywords: Bacillus subtilis, Characterization, Inhibition, Milk-clotting activity

\section{INTRODUCTION}

Calf chymosin (EC3.4.23.4) is widely used as a milk-clotting enzyme (MCE) in cheese production. However, a decrease in the global supply of calf rennet versus the increasing demand of chymosin in the production of cheese necessitates the exploration for potential substitutes (Hang et al., 2016). Milk-clotting enzymes from microbial sources have been discovered and developed to replace calf rennet (Ding et al., 2012).

Several microorganisms produce MCEs, with the MCEs produced by fungi such as Rhizomисоr miehei, Rhizomucor pusillus var. Lindt, Aspergillus oryzae and Endothia parasitica widely used in cheese production (Wu et al., 2013). Currently, researches on the production of milk-clotting enzyme from bacteria are less as compared to those from fungi (Ding et al., 2012). However, there exist some wild-type bacteria that produced milk-clotting enzymes with substantial milk-clotting activity (MCA) under submerged fermentation conditions (Dutt et al., 2008).

Bacteria of genus Bacillus are known for the production of large quantities of extracellular proteases and other types of enzymes for industrial use (Ageitos et al., 2007). In particular, the well-researched Bacillus subtilis is known to secrete several enzymes of industrial importance (Kumari et al., 2016). The present study describes the production and partial characterization of a milk-clotting proteinase from Bacillus subtilis SMDFS-2B that was isolated by our laboratory.

\section{MATERIALS AND METHODS}

\section{Strain and Cultivation Conditions}

The bacterium used in the present study was isolated from soil collected from

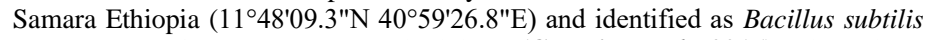
SMDFS-2B using 16S rRNA methodology (Guleria et al., 2016). The culture medium as employed by us contained: galactose $(20 \mathrm{~g} / \mathrm{L})$, wheat bran $(30 \mathrm{~g} / \mathrm{L})$, sodium chloride $(5 \mathrm{~g} / \mathrm{L})$, magnesium sulfate $\left(\mathrm{MgSO}_{4} \cdot 7 \mathrm{H}_{2} \mathrm{O}, 5 \mathrm{~g} / \mathrm{L}\right)$, potassium phosphate $\left(\mathrm{KH}_{2} \mathrm{PO}_{4}, 2 \mathrm{~g} / \mathrm{L}\right)$ and calcium carbonate $(3 \mathrm{~g} / \mathrm{L})$. Final $\mathrm{pH}$ was adjusted to 5.5 . The culture medium was sterilized by autoclaving at $121{ }^{\circ} \mathrm{C}$ for $20 \mathrm{~min}$. Subsequently, the media was inoculated with $4 \%$ inoculum suspension $\left(2.5^{*} 10^{8}\right.$ cells per $\mathrm{mL}$ ) and incubated for $72 \mathrm{~h}$ using an orbital shaker $(150 \mathrm{rpm})$ at $35{ }^{\circ} \mathrm{C}$ (Ding et al., 2012).

\section{Crude enzyme preparation (Dialysis)}

Samples were collected after $72 \mathrm{~h}$ under aseptic conditions and centrifuged at 10,000 rpm (MaxQ 2000 Open-Air Platform Shaker, Thermo Fisher Scientific, USA) for $10 \mathrm{~min}$. The supernatant was collected by decantation and tested for milk-clotting activity (Ding et al., 2012). The clarified culture supernatant was subjected to dialysis using $8-10 \mathrm{~cm}$ of dialysis membrane (10 kDA cut-off) immersed in $100 \mathrm{ml}$ of $2 \%$ sodium carbonate solution and kept in the refrigerator at $4{ }^{\circ} \mathrm{C}$. The liquid crude enzyme extract was poured in to a membrane tied with rubber tightly on one side and then the other side of the membrane was tied again with rubber. A powder of carboxymethyl cellulose salt was added to the membrane and the membrane was spread over a flat plate for overnight. Finally the residual protein in the membrane was collected from membrane by dipping with sodium phosphate buffer $(20 \mathrm{mM}, \mathrm{pH}=6.0)$ (Ramachandran and Arutselvi, 2013).

\section{Protein determination}

Total protein was determined using Bicinchonic acid (BCA) method (Walker, 2002) using bovine serum albumin (BSA) (Thermo Scientific ${ }^{\mathrm{TM}}$ ) as a standard. Milk-clotting Assay

Milk-clotting activity was performed according to Arima et al., (1970). Briefly, $0.1 \mathrm{~mL}$ of the crude enzyme was added to $1.0 \mathrm{~mL}$ of reconstituted skim-milk $\left(\mathrm{Nestle}^{\mathrm{TM}}\right)$ in $5.0 \mathrm{~mL}$ test tubes that were pre-incubated at $35^{\circ} \mathrm{C}$ for $10 \mathrm{~min}$. The enzyme substrate consisted of $10 \mathrm{~g}$ dry skim-milk/100 $\mathrm{mL}$ in $0.01 \mathrm{M} \mathrm{CaCl}_{2}$ (AppliChemTM). The appearance of the first clotting flakes was visually evaluated and the activity quantified in terms of Soxhlet Units (SU). The endpoint was recorded when discrete particles were discernible. The clotting time $\mathrm{T}(\mathrm{s})$, the period from the addition of crude enzyme to the appearance of the first clots was employed to calculate the clotting activity using the following formula:

$$
S U=(2400 * 1 * D) /(T * 0.1)
$$

Where $T=$ clotting time $(s)$ and $D=$ dilution of crude enzyme preparation One $\mathrm{SU}$ is expressed as the quantity of enzyme required to clot $1.0 \mathrm{~mL}$ of a solution comprising $0.1 \mathrm{~g}$ skim-milk powder and $0.01 \mathrm{M}$ calcium chlorides at 35 ${ }^{0} \mathrm{C}$ within 40 min.

\section{Proteolytic activity Assay}

The proteolytic activity was assayed according to Arima et al., (1970). Thus, 0.5 $\mathrm{mL}$ of the enzyme extract was added to $2.5 \mathrm{~mL}$ of $1 \%(\mathrm{w} / \mathrm{v})$ soluble casein in 20 $\mathrm{mM}$ potassium phosphate buffer at $\mathrm{pH} 6.5$, and the mixture was incubated in a water bath at $35{ }^{\circ} \mathrm{C}$ for $10 \mathrm{~min}$. After having added $2.5 \mathrm{~mL}$ of $0.44 \mathrm{M}$ trichloroacetic acid to terminate the reaction, the mixture was filtered through Whatman No.1 filter paper. The filtrate was then mixed with $1.0 \mathrm{~mL}$ volume of three times diluted $2 \mathrm{~N}$ Folin-Phenol reagent and $2.5 \mathrm{~mL}$ of $0.55 \mathrm{M}$ sodium carbonate solution. The mixture was incubated at $35{ }^{\circ} \mathrm{C}$ for $20 \mathrm{~min}$ and optical density (OD) was measured with a spectrophotometer (UV-Vis, Liantrinsat, Model-CF728YW-UK) at $660 \mathrm{~nm}$. One unit $(1 \mathrm{U})$ of enzyme activity was 
defined as the amount of enzyme that liberated $1 \mu \mathrm{g}$ of tyrosine per $\mathrm{mL}$ in one minute.

$$
\mathrm{PA}(\mathrm{U} / \mathrm{mL})=\frac{\mu \mathrm{Tyr} * \mathrm{~V}_{\mathrm{t}}}{\mathrm{V}_{\mathrm{s}} * \mathrm{~T} * \mathrm{~V}_{\mathrm{a}}}
$$

Whereas PA: Protease activity, $\mu$ Try: $\mu \mathrm{g}$ of tyrosine equivalent released, Vt: Total volume of assay in $\mathrm{mL}(5 \mathrm{~mL}$ of substrate plus $1 \mathrm{ml}$ of Enzyme plus $5 \mathrm{ml}$ of TCA), Vs: Sample volume (ie. The volume of protease used for assay in $\mathrm{mL}$ ), T: reaction time (i.e Time of incubation in minutes, $10 \mathrm{~min}$ ), Va: Volume of assayed (i.e the final volume of the product used in calorimetric determination)

\section{Inhibition Studies}

The effects of known protease inhibitors on the milk-clotting activity of the dialyzed enzyme were examined using cysteine protease inhibitor, iodoacetamide $(1 \mathrm{mM}$ and $10 \mathrm{mM})$; aspartic protease inhibitor, pepstatin A $(0.02 \mathrm{mM}, 0.04 \mathrm{mM}$, $0.6 \mathrm{mM}, 0.08 \mathrm{mM}$ and $0.1 \mathrm{mM})$; metalloprotease inhibitor, EDTA $(5 \mathrm{mM}, 10 \mathrm{mM})$; and serine protease inhibitor, phenylmethane sulphonyl fluoride (PMSF) (1mM, $10 \mathrm{mM})$. After the addition of inhibitors into the enzyme samples, the mixtures were incubated at $35{ }^{\circ} \mathrm{C}$ for $30 \mathrm{~min}$., the residual milk-clotting activity was then assayed. Residual activity was defined as the percentage of the activity determined in the absence of inhibitors (Yegin et al., 2012).

\section{Determination of optimum temperature and thermal stability}

For the determination of the optimum temperature of the dialyzed enzyme, the milk-clotting activity of the reaction mixture $(10 \%$ skim milk (w/v) in $0.01 \mathrm{M}$ $\left.\mathrm{CaCl}_{2}\right)$ was assayed at different temperature $(25,30,35,40,45,50,55,60,65$ and $70{ }^{\circ} \mathrm{C}$ ). Likewise, the thermal stability was determined by incubating the crude enzyme at a temperature in the range of $\left(35,40,45,50,55\right.$ and $\left.60{ }^{\circ} \mathrm{C}\right)$ for 15 and $30 \mathrm{~min}$. After incubation, the samples were cooled in an ice bath prior to assay for determination of residual milk clotting activity (Yegin et al., 2012).

\section{Determination of optimum $\mathrm{pH}$ and $\mathrm{pH}$ stability}

The substrate (skim milk) containing $0.01 \mathrm{M} \mathrm{CaCl}_{2}$ was prepared at $\mathrm{pH}(4.5,5.0$, $5.5,6.0)$ using $20 \mathrm{mM}$ citrate-buffer, while $\mathrm{pH}(6.5,7.0,7.5$ and 8.0) solutions were prepared using $10 \mathrm{mM}$ potassium phosphate buffer. Then the optimum $\mathrm{pH}$ of the dialyzed enzyme was determined by carrying out the milk-clotting assay according to section 2.4. The $\mathrm{pH}$ stability was determined by incubating the dialyzed enzyme sample in $20 \mathrm{mM}$ citrate buffer having $\mathrm{pH}(4.5,5.0,5.5$, and 6.0) and in $10 \mathrm{mM}$ potassium phosphate buffer $\left(6.5,7.0,7.5\right.$ and 8.0) at $25^{\circ} \mathrm{C}$ for 30 minutes. After incubation, the samples were examined for relative milkclotting activity (Ageitos et al., 2007; Yegin; et al., 2012)

\section{Effect of substrate concentration on the milk-clotting activity}

To determine the effect of substrate concentration on the milk-clotting activity of the dialyzed enzyme, the skim-milk solution with different concentration $(25 \mathrm{~g} / \mathrm{L}$, $50 \mathrm{~g} / \mathrm{L}, 100 \mathrm{~g} / \mathrm{L}, 150 \mathrm{~g} / \mathrm{L}$ and $200 \mathrm{~g} / \mathrm{L}$ ) were prepared and the standard milkclotting activity was determined as previously described in section 2.4. The highest activity obtained was taken to be $100 \%$ (El-Tanboly et al., 2013).

\section{The impact of additives on the milk-clotting activity}

The effect of various metal ions $\left(\mathrm{Na}^{+}, \mathrm{K}^{+}, \mathrm{Ca}^{2+,} \mathrm{Mg}^{2+} \mathrm{Mn}^{2+}, \mathrm{Fe}^{2+}, \mathrm{Zn}^{2+}, \mathrm{Ni}^{2+}, \mathrm{Cu}^{2+}\right.$, and $\mathrm{Co}^{2+}$ ) on the milk-clotting activity was studied. First the metal salts in the forms of chloride and sulfate were added in the skim-milk substrate at a final concentration of $10 \mathrm{mM}$ and then the milk-clotting assay was conducted after 30 minutes (Table 1). For comparison, the control (without the addition of any metal ion) was taken or set as $100 \%$ and the effect of various metal ions was expressed as or relative activity (Kumari et al., 2016).

Table 1 Metals ions used for milk-clotting assay

\begin{tabular}{lll}
\hline \hline S.No & Type of Metal Ions & Concentrations \\
\hline \hline & $\begin{array}{l}\text { Control (without adding } \\
\text { any metal ion) }\end{array}$ & - \\
\hline 2. & $\mathrm{NaCl}$ & $10 \mathrm{mM}$ \\
\hline 3. & $\mathrm{KCl}$ & $10 \mathrm{mM}$ \\
\hline 4. & $\mathrm{CaCl}_{2}$ & $10 \mathrm{mM}$ \\
\hline 5. & $\mathrm{MgCl}_{2}$ & $10 \mathrm{mM}$ \\
\hline 6. & $\mathrm{FeCl}_{2}$ & $10 \mathrm{mM}$ \\
\hline 7. & $\mathrm{MnCl}_{2}$ & $10 \mathrm{mM}$ \\
\hline 8. & $\mathrm{NiCl}_{2}$ & $10 \mathrm{mM}$ \\
\hline 9. & $\mathrm{MgSO}_{4} \cdot 7 \mathrm{H}_{2} \mathrm{O}$ & $10 \mathrm{mM}$ \\
\hline 10. & $\mathrm{MnSO}_{4} \cdot 7 \mathrm{H}_{2} \mathrm{O}$ & $10 \mathrm{mM}$ \\
\hline 11. & $\mathrm{ZnSO}_{4} \cdot 7 \mathrm{H}_{2} \mathrm{O}$ & $10 \mathrm{mM}$ \\
\hline 12. & $\mathrm{CuSO}_{4} \cdot 7 \mathrm{H}_{2} \mathrm{O}$ & $10 \mathrm{mM}$ \\
\hline 13. & $\mathrm{FeSO}_{4} \cdot 7 \mathrm{H}_{2} \mathrm{O}$ & $10 \mathrm{mM}$ \\
\hline 14. & $\mathrm{CoSO}_{4}$ & 10 \\
\hline
\end{tabular}

\section{Effect of $\mathrm{MnSO}_{4}$ and $\mathrm{CaCl}_{2}$ concentration on the milk-clotting activity}

To study the effect of $\mathrm{MnSO}_{4}$ and $\mathrm{CaCl}_{2}$ on the clotting efficiency of the dialyzed enzyme, various concentrations of $\mathrm{MnSO}_{4}$ and $\mathrm{CaCl}_{2}(0.00 \mathrm{M}, 0.005 \mathrm{M}, 0.01 \mathrm{M}$, $0.05 \mathrm{M}, 0.1 \mathrm{M}$, and $0.2 \mathrm{M}$ ) were incorporated in the reaction mixture (Table 2). Time taken for the appearance of the first clot was recorded and compared with the control sample (El-Tanboly et al., 2013).

Table 2 Concentration of $\mathrm{MnSO}_{4}$ and $\mathrm{CaCl}_{2}$ used for milk-clotting assay

\begin{tabular}{lcc}
\hline \hline S.No & Conc. Of $\mathrm{MnSO}_{4}$ in $\mathrm{mM}$ & Conc. of $\mathrm{CaCl}_{2}$ in $\mathrm{mM}$ \\
\hline \hline 1 & 0.00 & 0.00 \\
\hline 1. & 5.00 & 5.00 \\
\hline 2. & 10.00 & 10.00 \\
\hline 3. & 50.00 & 50.00 \\
\hline 4. & 100.00 & 100.00 \\
\hline 5. & 200.00 & 200.00 \\
\hline \hline
\end{tabular}

\section{Data analysis}

Data analyses were performed using SAS software version 9 (Inc. Cary NC USA). The experiments were carried out in triplicate. Analysis of variance (ANOVA) and means comparisons were done by Duncan's multiple range tests.

\section{RESULTS}

\section{Crude enzyme production and partial purification}

Bacillus subtilis SMDFS 2B was cultivated in shaking flasks under submerged fermentation conditions utilizing a simple media containing wheat bran, under partially optimized conditions (Table 3 ). The maximum milk-clotting activity $(312 \mathrm{U} / \mathrm{mL})$ was recorded in the culture supernatant after $72 \mathrm{~h}$ of fermentation. The culture supernatant was dialyzed and concentrated to yield a crude enzyme preparation. The milk-clotting activity was increased 2.0-fold after dialysis (Table 4).

Table 3 Production of crude enzyme from B. subtilis SMDFS2B under SmF

\begin{tabular}{lc}
\hline \hline Parameters & Measurement Unit \\
\hline \hline Initial media $\mathrm{pH}$ & 5.5 \\
\hline Inoculum size & $4 \%$ of $\left(2.5^{*} 10^{8} \mathrm{Cells} / \mathrm{mL}\right)$ \\
\hline Fermentation time & $72 \mathrm{~h}$ \\
\hline rpm & 150 \\
\hline MCA & $311.74 \pm 4.05 \mathrm{U} / \mathrm{mL}$ \\
\hline PA & $231.04 \pm 5.18 \mathrm{U} / \mathrm{mL}$ \\
\hline \hline $\begin{array}{l}\text { rpm: revolution per minute, MCA: Milk-clotting activity }(\mathrm{U} / \mathrm{mL}), \text { PA: protease activity } \\
(\mathrm{U} / \mathrm{mL})\end{array}$
\end{tabular}


Table 4 MCA, specific activity and concentration fold of dialyzed protease from B.subtilis SMDFS 2B

\begin{tabular}{lcccc}
\hline \hline Sample & $\begin{array}{c}\text { MCA }(\mathrm{U} / \mathrm{mL}) \\
\text { Mean } \pm \mathrm{SD}\end{array}$ & $\begin{array}{c}\text { Protein } \\
\text { conc. } \\
(\mathrm{mg} / \mathrm{mL})\end{array}$ & $\begin{array}{c}\text { Specific activity } \\
(\mathrm{U} / \mathrm{mg})\end{array}$ & $\begin{array}{c}\text { Purification } \\
\text { Fold }\end{array}$ \\
\hline \hline $\begin{array}{l}\text { Crude } \\
\text { enzyme }\end{array}$ & $311.74 \pm 4.05^{\mathrm{b}}$ & 17.67 & 17.64 & 1 \\
\hline $\begin{array}{l}\text { Dialyzed } \\
\text { enzyme }\end{array}$ & $406.90 \pm 6.90^{\mathrm{a}}$ & 11.13 & 36.56 & 2.07 \\
\hline \hline
\end{tabular}

MCA: Milk-clotting activity (U/mL), specific activity: MCA (U/mL)/Total protein $(\mathrm{mg} / \mathrm{mL})$, SD: standard deviation, Mean: is average of three measurements, Different letters $(a, b$, designate significantly different means as determined by Duncan multiple mean comparison test $(\mathrm{P}<0.05)$.

\section{Inhibition study}

The type of milk-clotting proteinase produced by B. subtilis SMDFS 2B was determined by conducting inhibition experiments using four protease inhibitors. Incubation of the enzyme with individual protease inhibitors showed a significant reduction in milk-clotting activity. Residual milk-clotting activity values of $27 \%$, $43 \%, 7.9 \%$ and $37 \%$ were found when using Pepstatin A $(0.1 \mathrm{mM})$, Iodoacetamide $(10 \mathrm{mM})$, EDTA $(10 \mathrm{mM})$ and PMSF $(10 \mathrm{mM})$, respectively (Table 5).

Table 5 Inhibition study of the dialyzed enzyme from B.subtilis SMDFS 2B

\begin{tabular}{|c|c|c|c|}
\hline Inhibitors & Conc. in $\mathrm{mM}$ & $\begin{array}{c}\mathrm{MCA}(\mathrm{U} / \mathrm{ml}) \\
\text { mean } \pm \mathrm{SD}\end{array}$ & $\begin{array}{c}\text { Residual MCA } \\
(\%)\end{array}$ \\
\hline \multirow{5}{*}{ Pepstatin A } & $0.02 \mathrm{mM}$ & $279.11 \pm 3.25^{\mathrm{b}}$ & 68.59 \\
\hline & $0.04 \mathrm{mM}$ & $193.30 \pm 10.09^{d}$ & 47.51 \\
\hline & $0.06 \mathrm{mM}$ & $160.58 \pm 2.69^{\mathrm{fg}}$ & 39.46 \\
\hline & $0.08 \mathrm{mM}$ & $147.13 \pm 10.77^{\mathrm{g}}$ & 36.16 \\
\hline & $0.1 \mathrm{mM}$ & $108.68 \pm 2.95^{\mathrm{h}}$ & 26.71 \\
\hline \multirow{2}{*}{ Iodoacetamide } & $1 \mathrm{mM}$ & $214.30 \pm 1.91^{\mathrm{c}}$ & 52.67 \\
\hline & $10 \mathrm{mM}$ & $175.19 \pm 1.28^{\mathrm{e}}$ & 43.06 \\
\hline \multirow{2}{*}{ EDTA } & $5 \mathrm{mM}$ & $177.12 \pm 0.65^{\mathrm{e}}$ & 43.53 \\
\hline & $10 \mathrm{mM}$ & $32.32 \pm 0.02^{\mathrm{i}}$ & 7.94 \\
\hline \multirow{2}{*}{ PMSF } & $1 \mathrm{mM}$ & $161.54 \pm 8.67^{\mathrm{f}}$ & 39.70 \\
\hline & $10 \mathrm{mM}$ & $150.47 \pm 0.47^{\mathrm{tg}}$ & 36.98 \\
\hline $\begin{array}{l}\text { Control (dialyzed } \\
\text { Enzyme) }\end{array}$ & - & $406.90 \pm 6.90^{\mathrm{a}}$ & 100.00 \\
\hline
\end{tabular}

ND: Not determined, MCA: Milk-clotting activity (U/mL), Pep A: Pepstatin A, I.A: Iodoacetamide, EDTA: ethylenediaminetetraacetic acid, PMSF: phenyl-methane sulphonyl fluoride, SD: standard deviation, Mean: is average of three measurements, different letters (a, b, c, d, e, f, g) designate significantly different means as determined by Duncan multiple mean comparison test $(\mathrm{P}<0.05)$.

\section{Effects of temperature on enzyme activity and stability}

In determination of the optimum temperature for the dialyzed enzyme, the milkclotting activity was assayed at the temperature range from $25^{\circ} \mathrm{C}$ to $70{ }^{\circ} \mathrm{C}$ using skim-milk at $\mathrm{pH}$ 6.2. The highest milk-clotting activity $(2833 \mathrm{U} / \mathrm{mL})$ for the dialyzed milk-clotting protease from $B$. subtilis SMDFS-2B was obtained at 55 ${ }^{\circ} \mathrm{C}$. Thereafter, the milk-clotting activity of the enzyme drastically decreased and insignificant activity was observed at $70{ }^{\circ} \mathrm{C}$ (Fig 1). Thermal inactivation experiments were conducted at a temperature ranges from $35{ }^{\circ} \mathrm{C}$ to $60{ }^{\circ} \mathrm{C}$ using skim-milk at $\mathrm{pH}$ 6.2. The dialyzed enzyme from $B$. subtilis SMDFS-2B showed stability on incubation at $35{ }^{\circ} \mathrm{C}$ and $40{ }^{\circ} \mathrm{C}$ for $15 \mathrm{~min}$ by exhibiting a residual activity of $81 \%$ and $74 \%$, respectively. However; the residual activity of the enzyme preparation slightly decreased to $55 \%$ after incubating at $60{ }^{\circ} \mathrm{C}$ for 15 min. Further increase in incubation time to $30 \mathrm{~min}$ drastically reduced the milkclotting ability of the enzyme (Fig. 2).

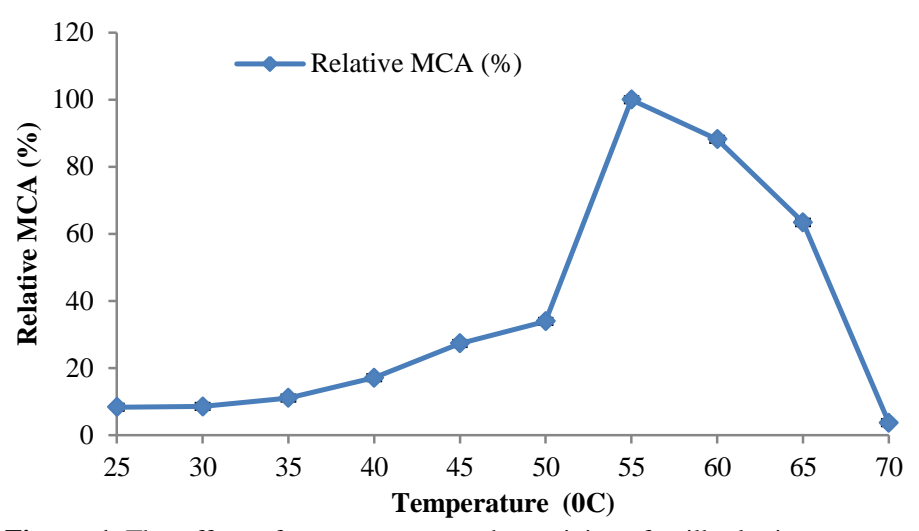

Figure 1 The effect of temperature on the activity of milk-clotting protease produced by B. subtilis SMDFS 2

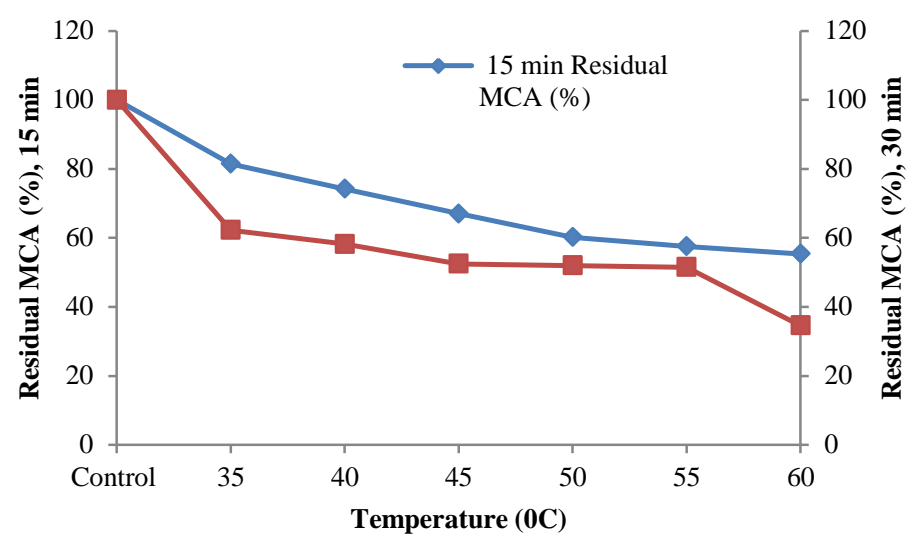

Figure 2 The effect of temperature on the stability of milk-clotting protease produced by B. subtilis SMDFS2B

\section{Effect of pH on enzyme activity and stability}

The effect of $\mathrm{pH}$ on the milk-clotting activity of the dialyzed enzyme was studied at $\mathrm{pH}$ ranges from 4.0 to 8.0 at $35^{\circ} \mathrm{C}$. The enzyme exhibited the maximal rate of reaction at a pH range (4.0-6.0) as shown in Fig. 3. However, the highest milkclotting activity $(375 \pm 6 \mathrm{U} / \mathrm{mL})$ was obtained at $\mathrm{pH} 5.5$. The stability of the dialyzed enzyme at different $\mathrm{pH}$ values is shown in Fig. 3. The enzyme showed maximum stability at $\mathrm{pH} 5.5$. As the $\mathrm{pH}$ becomes extreme to either side, the activity of the enzyme decreased significantly.

\section{Effect of skim-milk concentration on enzyme activity}

The effect of skim-milk concentration $(25 \mathrm{~g} / \mathrm{L}-200 \mathrm{~g} / \mathrm{L})$ on the milk-clotting activity of the dialyzed enzyme is shown in Fig. 4. The enzyme showed an elevation in its milk-clotting activity with increasing skim-milk concentration (Fig. 4). The MCA reached a maximum when the skim-milk concentration was increased to $200 \mathrm{~g} / \mathrm{L}$. 


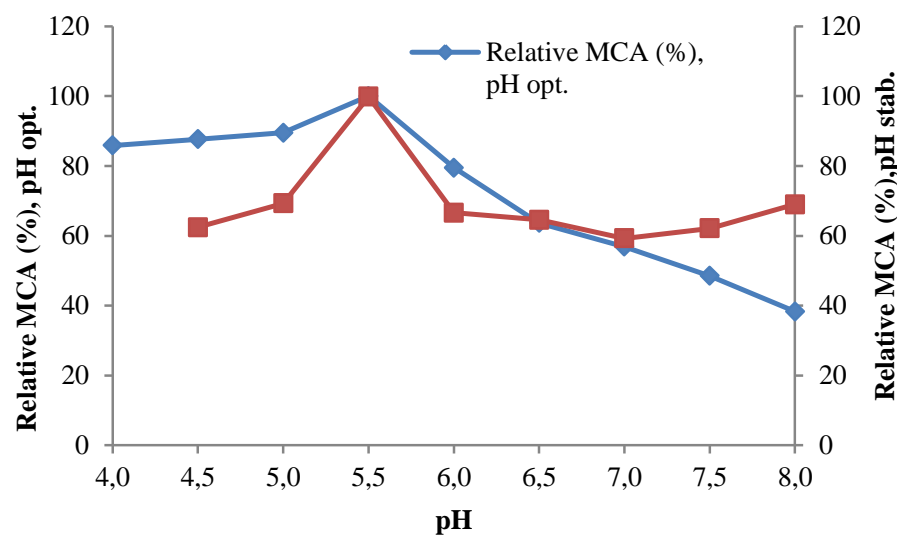

Figure 3 The effect of $\mathrm{pH}$ on the activity and stability of milk-clotting protease produced by $\mathrm{B}$. subtilis SMDFS 2B

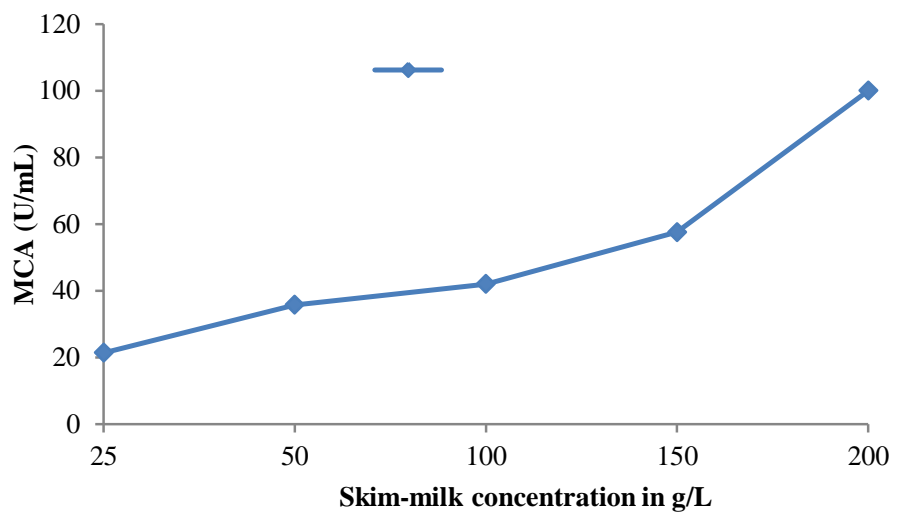

Figure 4 The effect of skim-milk concentration on the activity of milk-clotting protease from B.subtilis SMDFS 2B

\section{Effect of metal ions on enzyme activity}

The effect of various monovalent and divalent ions on the milk-clotting activity of the dialyzed enzyme from $B$. subtilis SMDFS-2B was studied at $10 \mathrm{mM}$ concentration (Fig. 5). $\mathrm{Na}^{+}, \mathrm{K}^{+}$, and $\mathrm{Zn}^{2+}$ had a slight stimulatory effect on milkclotting activity, whereas $\mathrm{Cu}^{2+} \mathrm{Co}^{2+}$, and $\mathrm{Ni}^{2+}$ significantly inhibited the milkclotting activity. In contrast, $\mathrm{Mg}^{2+}$ and $\mathrm{Mn}^{2+}$ had a significant stimulatory effect on the milk-clotting activity of the crude enzyme from B. subtilis SMDFS-2B.

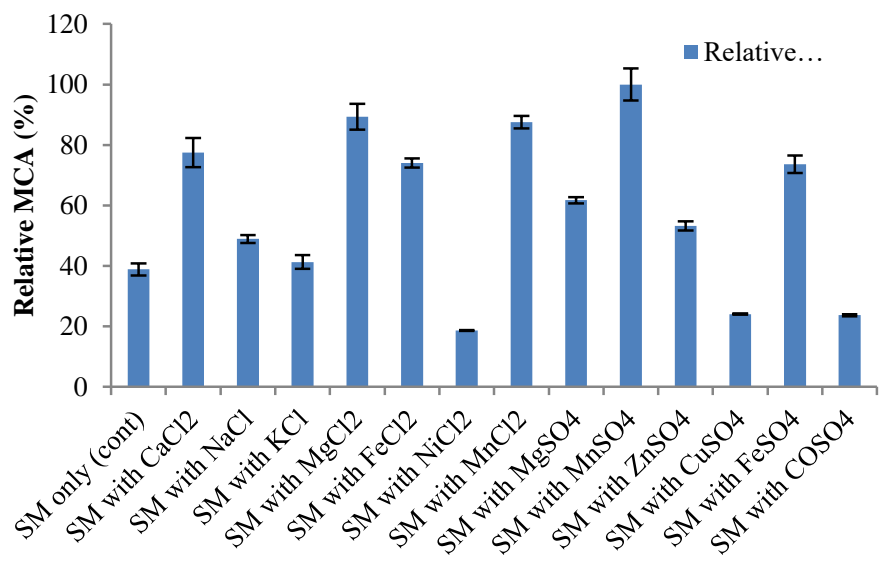

Metal ions (10 mM)

Figure 5 The effect of metal-ions on activity of milk-clotting protease from B.subtilis SMDFS 2B
Effect of $\mathrm{CaCl}_{2}$ and $\mathrm{MnSO}_{4}$ concentration on enzyme activity

The effect of $\mathrm{CaCl}_{2}$ and $\mathrm{MnSO}_{4}$ concentration on the milk-clotting activity of the dialyzed enzyme from $B$. subtilis SMDFS-2B was studied in the range from 5 $\mathrm{mM}$ to $200 \mathrm{mM}$. The highest milk-clotting activity was obtained at $10 \mathrm{mM}$ and $50 \mathrm{mM}$ concentration of $\mathrm{MnSO}_{4}$ and $\mathrm{CaCl}_{2}$, respectively (Fig. 6). The clotting time increased with increasing concentration of $\mathrm{Ca}^{2+}$ and reached the maximum at $50 \mathrm{mM}$ and thereafter declined severely. The milk clotting activity of the crude enzyme also increased with increasing concentration of $\mathrm{Mn}^{2+}$ and reached highest at $10 \mathrm{mM}$ and reduced sharply afterward.

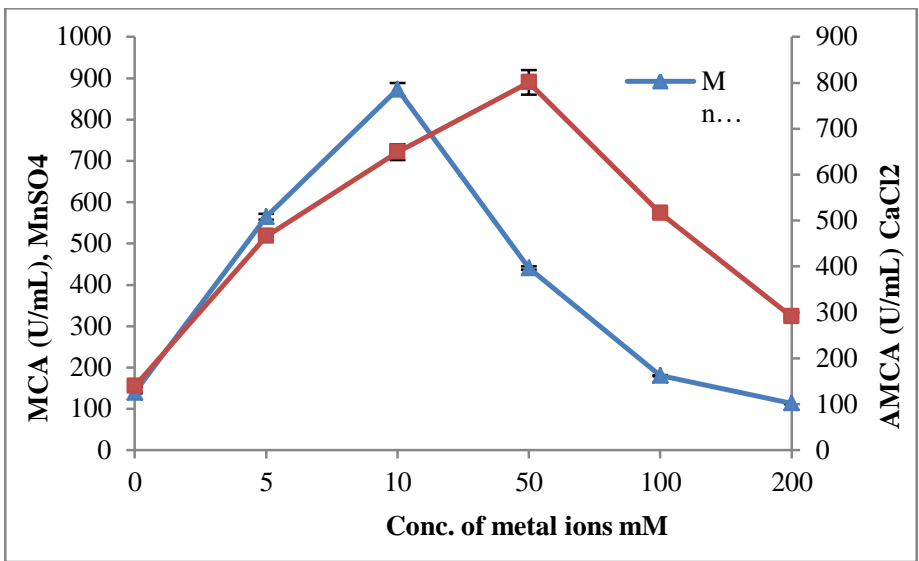

Figure 6 The effect of $\mathrm{MnSO}_{4}$ and $\mathrm{CaCl}_{2}$ concentration on the activity of milkclotting protease produced by B.subtilis SMDFS 2B

\section{DISCUSSION}

The milk-clotting activity of the crude enzyme preparation $(312 \pm 4 \mathrm{U} / \mathrm{mL})$ obtained from B. subtilis SMDFS-2B in the present study was higher when compared to the activity recorded for crude milk-clotting protease from Thermomucor indicae-seudaticae N31 (160 $\pm 12 \mathrm{U} / \mathrm{mL})$ (Merheb-Dini et al., 2010) and from Bacillus amyloliquefaciens SP1(130 U/mL) (Guleria et al., 2016). However, a higher activity $(1190 \mathrm{U} / \mathrm{mL})$ was obtained from an indigenous Bacillus subtilis strain after the production media was optimized using response surface methodology (RSM) (Dutt $\boldsymbol{e t}$ al., 2009). The variation recorded in milkclotting activity could be due to the differences in microbial strain and/or media used for the enzyme production.

Dialyzing the crude enzyme resulted in an increase in the milk-clotting activity of the preparation by 2 -fold. This may be due to the removal of low-molecularweight interfering or inhibitory compounds. Similarly, partial purification of a milk-clotting protease from M. pusillus (Nouani et al., 2011), a serine alkaline protease from B. mojavensis (Beg and Gupta, 2003) and mixed proteases from B. amyloliquefaciens (Cho et al., 2002) using 70-85\% saturated ammonium sulfate increased their activity values by 3 -fold, 6 -fold, and 2.5 -fold, respectively. However, partial purification of a novel protease from B. licheniformis strain $\mathrm{K} 7 \mathrm{~A}$ by $(\mathrm{NH} 4)_{2} \mathrm{SO}_{4}$ fractionation $(40-70 \%)$ plus dialysis increased the enzyme activity by 12 -fold (Hadjidj et al., 2018).

The activity of the dialyzed enzyme was strongly inhibited in the presence of pepstatin $(0.1 \mathrm{mM})$, iodoacetamide $(10 \mathrm{mM})$, EDTA $(10 \mathrm{mM})$ and PMSF $(10$ $\mathrm{mM})$. The results of the inhibition study suggested that the enzyme preparation could contain all the four types of protease classes (Aspartic, Cysteine, and Serine and Metallo-proteases). Further purification studies or analytical fractionation of the crude enzyme would be required to elucidate this point with certainty. However, the low residual activity observed in the presence of pepstatin A (27\%) could indicate the existence of one (or more) aspartic proteinase(s) in the crude enzyme mixture. However, it is interesting to observe that the activity of a purified serine alkaline protease from $B$. mojavensis was completely inhibited by more than one protease inhibitor agents; specifically PMSF (1mM) and iodoacetic acid (1mM) (Beg and Gupta, 2003). In contrast, the activities of milk-clotting protease from $B$. licheniformis USC13 (Ageitos et al., 2007) and novel protease from $B$. licheniformis K7A (Hadjidj et al., 2018) 
were completely inhibited only by PMSF. In other studies, the milk-clotting activities of purified milk-clotting aspartic protease from Withania coagulants fruit were exclusively suppressed by pepstatin A $(0.08 \mathrm{mM})$ (Salehia et al., 2017).

In the present study, the dialyzed enzyme from $B$. subtilis SMDFS-2B showed maximum activity at $55^{\circ} \mathrm{C}$. Similar to the present work, the purified milk-clotting enzyme from B. sphaericus (El-Bendary et al., 2007) and B. subtilis natto (Wu et al., 2013) showed optimal milk-clotting activity at $55{ }^{\circ} \mathrm{C}$ and $60{ }^{\circ} \mathrm{C}$, respectively. However, milk-clotting activity from B. licheniformis 5A5 (Ahmed and Helmy, 2012) and B. amyloliquefaciens JNU002 (Ding et al., 2012) that showed maximum activity at $75{ }^{\circ} \mathrm{C}$ and $70{ }^{\circ} \mathrm{C}$, respectively, are more thermotolerant than the proteinase from $B$. subtilis SMDFS-2B (this study). Different from the present study, the highest milk-clotting activity for milk-clotting protease from B. licheniformis USC13 (Ageitos et al., 2007) and purified enzyme from B. subtilis MTCC 10422 (Kumari et al., 2016) were obtained at $37{ }^{\circ} \mathrm{C}$ and $45^{\circ} \mathrm{C}$, respectively.

The thermal stability of the rennet enzyme was one of the most important criteria with respect to its potential applications. In this study, the result of the enzyme preparation from B. subtilis SMDFS-2B showed significant thermal stability. However, the MCA of the dialyzed enzyme was considerably reduced upon exposure at $60{ }^{\circ} \mathrm{C}$. The enzyme retained $55 \%$ of its original activity after heating at $60{ }^{\circ} \mathrm{C}$ for $15 \mathrm{~min}$; further incubation of the enzyme at $60{ }^{\circ} \mathrm{C}$ for $30 \mathrm{~min}$ caused a dramatic loss of its activity to $35 \%$. The loss of milk-clotting activity upon increasing the reaction temperature may be interpreted to be due to the denaturation of the enzyme above the verified temperature (Wehaidya et al., 2016) and this maybe a technological advantage since no bitterness development can occur during cheese ripening due to the inactivated proteolytic action of the enzyme after the cooking process of the curd (Sousa et al., 2001).

The residual activity obtained for bacterial rennet from B. licheniformis 5A5 (73.4\%) upon exposure for $1 \mathrm{~h}$ at $40{ }^{\circ} \mathrm{C}$ (Ahmed and Helmy, 2012), MCE from $B$. subtilis (81.3\%) after incubation for $10 \mathrm{~min}$ at $55{ }^{\circ} \mathrm{C}$ (Ding et al., 2011), enzyme from B. amyloliquefaciens JNU002 $(52.84 \%)$ after incubating for $20 \mathrm{~min}$ at 50 ${ }^{\circ} \mathrm{C}$ (Ding et al., 2012), enzyme from B. sphaericus (30\% ) after $20 \mathrm{~min}$ incubation at $60{ }^{\circ} \mathrm{C}$ (El-Bendary et al., 2007), enzyme from B. subtilis natto (47\%) after incubation for $40 \mathrm{~min}$ at $55^{\circ} \mathrm{C}$ (Shieh et al., 2009) and enzyme from B. subtilis natto (50\%) after incubation at $60{ }^{\circ} \mathrm{C}$ for $20 \mathrm{~min}$ (Wu et al., 2013) were comparable with the present study.

The $\mathrm{pH}$ had a significant effect on the activity of the milk-clotting enzyme. The dialyzed enzyme obtained from $B$. subtilis SMDFS-2B showed the highest milkclotting activity at $\mathrm{pH}$ 5.5. The result from the current study inferred that the enzyme works best at acidic $\mathrm{pH}$ than alkaline $\mathrm{pH}$. Similar to the present study, the maximal activity for milk-clotting enzyme from B. subtilis (Wehaidya et al., 2016), B. subtilis B1(Ding et al., 2011), B. amyloliquefaciens D4 (He et al., 2011), B. amyloliquefaciens JNU002 (Ding et al., 2012), B. subtilis natto (Wu et al., 2013) and B. subtilis MTCC 10422 (Kumari et al., 2016) were shown at $\mathrm{pH}$ $5.0,5.5$, and 6.0, respectively. On the other hand, the highest activities for milkclotting protease from $B$. licheniformis strain USC13 (Ageitos et al., 2007) and milk-clotting enzyme from B. sphaericus (El-Bendary et al., 2007) were obtained at $\mathrm{pH} 7.5$ and $6.0-7.5$, respectively.

The enzyme showed a narrow range of $\mathrm{pH}$ stability after incubation at different $\mathrm{pH}$ at room temperature. The dialyzed enzyme retained $50-80 \%$ of its milkclotting activity upon incubation at $\mathrm{pH} 5.0-6.5$ for $1.0 \mathrm{~h}$. However, any change of $\mathrm{pH}$ at either end of these ranges caused a significant reduction in residual milkclotting activity. These findings are in accordance with values reported for purified milk-clotting enzymes from B. amyloliquefaciens JNU002 (Ding et al., 2012), B. amyloliquefaciens $D 4$ (He et al., 2011), B. subtilis natto (Shieh et al., 2009) and B. subtilis natto (Wu et al., 2013). In another study, the milk-clotting enzyme from B. subtilis MTCC 10422 was shown stability in both acidic and basic pH (Kumari et al., 2016).

The enzyme showed an increment in its MCA with increasing skim-milk concentration. The highest milk-clotting activity was achieved at $20 \%$ skim-milk concentration. However, the maximal enzyme activity for milk-clotting enzyme (MCE) from B. subtilis (Wehaidya et al., 2016), B. amyloliquefaciens D4 (He et al., 2011), B. licheniformis 5A5 (Ahmed and Helmy, 2012) and B. sphaericus (El-Bendary et al., 2007) were attained at $0.4 \%, 5 \%, 6 \%$ and $9 \%$ substrate concentration, respectively. The differences between the present finding and others could be inferred to the impurity and handling of the crude enzyme used in this study.

The effect of several metal ions on the MCA of the dialyzed enzyme was determined. The MCE was activated by most of the metal ions tested except $\mathrm{Ni}^{2+}$,
$\mathrm{Cu}^{2+}$, and $\mathrm{Co}^{2+}$. The activity of MCE extremely stimulated by $\mathrm{MnSO}_{4}, \mathrm{FeSO}_{4}$, $\mathrm{MnCl}_{2}, \mathrm{MgCl}_{2}$, and $\mathrm{CaCl}_{2}$. Similarly, $\mathrm{MCE}$ from B. licheniformis $5 \mathrm{~A} 5$ (ElBendary et al., 2007), B. subtilis (Ding et al., 2011), B. amyloliquefaciens D4 (He et al., 2011) and B. amyloliquefaciens JNU002 (Ding et al., 2012) were also strongly triggered by $\mathrm{Mn}^{2+}, \mathrm{Ca}^{2+}, \mathrm{Ca}^{2+}$, and $\mathrm{Ca}^{2+}$, respectively. In other studies, $\mathrm{Mg}^{2+}$ and $\mathrm{Mn}^{2+}$ also showed a stimulatory effect on the MCA of MCE from $B$. subtilis MTCC 10422 (Kumari et al., 2016). Whereas, $\mathrm{Ni}^{2+}, \mathrm{Cu}^{2+}$, and $\mathrm{Co}^{2+}$ inhibited the MCA of MCE from B. sphaericus (Ding et al., 2012; El-Bendary et al., 2007). Likewise, $\mathrm{Co}^{2+}$ was found to have an inhibitory effect on the MCA of MCE from B. subtilis MTCC 10422 (Kumari et al., 2016).

Calcium had a positive effect on the activity of the MCE. It has been described as important in milk clot formation when its concentration is high enough (He et al., 2011). It is known that $\mathrm{Ca}^{2+}$ combines with $\rho$-casein to form a firm clot during the second phase of the clotting process. The addition of $\mathrm{CaCl}_{2}$ to milk causes a reduction in milk-clotting time by rennet, this increases the rate of coagulation (Ahmed and Helmy, 2012). In the present study, the highest MCA of the dialyzed enzyme was obtained at $10 \mathrm{mM}$ and $50 \mathrm{mM}$ concentration of $\mathrm{MnSO}_{4}$ and $\mathrm{CaCl}_{2}$, respectively. Similar to this study, the maximum activity for $\mathrm{MCE}$ from B. subtilis B1 (Ding et al., 2011) and B. amyloliquefaciens JNU002 (Ding et al., 2012) were obtained at $50 \mathrm{mM}$ and $60 \mathrm{mM} \mathrm{CaCl}_{2}$ concentration respectively. On the other hand, the optimal milk-clotting activity for MCE from B. licheniformis 5A5 (Ahmed and Helmy, 2012) and B. amyloliquefaciens D4 (He et al., 2011) were detected at $10 \mathrm{mM}$ and $25 \mathrm{mM} \mathrm{CaCl}_{2}$ concentration respectively.

\section{CONCLUSION}

In the present study, the milk-clotting enzyme produced from B. subtilis SMDFS$2 \mathrm{~B}$ by submerged fermentation revealed attractive properties. The partial characterization results have been shown that the enzyme exhibited optimum activity at $55{ }^{\circ} \mathrm{C}$ and $\mathrm{pH}$ 5.5. Further studies on the purification and full characterization of the enzyme(s) present in the crude preparation are in preparation.

Acknowledgement: We would like to acknowledge the Department of Microbial, Cellular and Molecular Biology of Addis Ababa University and Downstream Processing Laboratory, Department of Life Sciences and Chemistry, Jacobs University, Bremen, Germany for the facilitation of laboratory space and provision of facilities.

Fund: This work was supported by Microbial, Cellular and Molecular Biology, Addis Ababa University. Partial support for this study was provided from Project NANOZYME, BMBF - EuroTransBio-9 (ETB-9) under Grant agreement no.031B0017C, Project CPW Biorefinery by European Union Seventh Framework Programme (FP7) ERANET-LAC under Grant agreement no. 01DN17028, Project MOPSACI, by European Union Seventh Framework Programme (FP7) BMBF - under Grant agreement no. 031B0307C and Jacobs University Bremen.

Competing interests: There is no conflict among the authors.

\section{Ethical statement: None required}

Data Availability: The experimental data used to support the findings of this study are included within the article.

\section{REFERENCES}

Ageitos, J. M., Vallejo, J. A., Sestelo, A. B. F., Poza, M., \& Villa, T. G. (2007) Purification and characterization of a milk-clotting protease from Bacillus licheniformis strain USC13. Journal of Applied Microbiology, 103, 2205-2213. http://doi.org/10.1111/j.1365-2672.2007.03460.x

Ahmed, S. A., \& Helmy, W. A. (2012). Comparative evaluation of Bacillus licheniformis 5A5 and Aloe variegata milk-clotting enzymes. Brazilian Journal of Chemical Engineering, 29(1), 69-76.

Arima, K., Yu, J., \& Iwasaki, S. (1970). Milk-Clotting Enzyme from Mucor pusillus var. Lindt. Methods in Enzymology, 19, 446-459.

Beg, Q. K., \& Gupta, R. (2003). Purification and characterization of an oxidation-stable, thiol-dependent serine alkaline protease from Bacillus mojavensis. Enzyme and Microbial Technology, 32, 294-304. 
Cho, S.-J., Oh, S.-H., Pridmore, R. D., Juillerat, M. A., \& Lee, C.-H. (2002). Purification and Characterization of Proteases from Bacillus amyloliquefaciens Isolated from Traditional Soybean Fermentation Starter. Journal of Agricultural and Food Chemistry, 2, 1-7.

Ding, Z., Liu, S., Gu, Z., Zhang, L., \& Zhang, K. (2011). Production of milkclotting enzyme by Bacillus subtilis B1 from wheat bran. African Journal of Biotechnology, 10(46), 9370-9378. http://doi.org/10.5897/AJB10.1647

Ding, Z., Wang, W., Wang, B., Ouyang, A., Xiao, S., Wang, Y., ... Shi, G. (2012). Production and characterization of milk-clotting enzyme from Bacillus amyloliquefaciens JNU002 by submerged fermentation. European Food Research and Technology, 234(3), 415-421. http://doi.org/10.1007/s00217-011$1650-2$

Dutt, K., Gupta, P., Saran, S., Misra, S., \& Rajendra, K. S. (2009). Production of Milk-Clotting Protease from Bacillus subtilis. Appl Biochem Biotechnol, 158, 761-772. http://doi.org/10.1007/s12010-008-8504-9

Dutt, K., Meghwanshi, G. K., Gupta, P., \& Saxena, R. K. (2008). Role of casein on induction and enhancement of production of a bacterial milk clotting protease from an indigenously isolated Bacillus subtilis. Letters in Applied Microbiology, 46(5), 513-518. http://doi.org/10.1111/j.1472-765X.2008.02324.X

El-Bendary, M. A., Moharam, M. E., \& Ali, T. H. (2007). Purification and Characterization of Milk Clotting Enzyme Produced by Bacillus sphaericus. Journal of Applied Sciences Research, 3(8), 695-699.

El-Tanboly, E.-S., El-Hofi, M., Youssef, Y. B., El-Desoki, W., \& Ismail, A. (2013). Utilization of salt whey from Egyptian Ras (cephalotyre) cheese in microbial milk clottingenzyme production. Acta Sci. Pol., Technol. Aliment., 12(1), 9-19.

Guleria, S., Walia, A., Chauhan, A., \& Shirkot, C. K. (2016). Optimization of milk-clotting enzyme production by Bacillus amyloliquefaciens SP1 isolated from apple rhizosphere. Bioresources and Bioprocessing, 3(3), 1-9. http://doi.org/10.1186/s40643-016-0108-6

Hadjidj, R., Badis, A., Mechri, S., Eddouaouda, K., Khelouia, L., Annane, R., ... BassemJaouadi. (2018). Purification, biochemical, and molecular characterization of novel protease from Bacillus licheniformis strain K7A. International Journal of Biological Macromolecules, 114, 1033-1048. http://doi.org/10.1016/j.ijbiomac.2018.03.167

Hang, F., Liu, P., QinboWang, Han, J., ZhengjunWu, Gao, C., ... Chen, W. (2016). High Milk-Clotting Activity Expressed by the Newly Isolated Paenibacillus spp. Strain BD3526. Molecules, 21(73), 1-14. http://doi.org/10.3390/molecules21010073

He, X., Ren, F., Guo, H., Zhang, W., Song, X., \& Gan, B. (2011). Purification and properties of a milk-clotting enzyme produced by Bacillus amyloliquefaciens D4. Korean J. Chem. Eng., 28(1), 203-208. http://doi.org/10.1007/s11814-010$\underline{0347-8}$

Kumari, R., Bhushan, B., Pal, A., Panwar, A., \& Malhotra, S. (2016). Purification , physico-chemico-kinetic characterization and thermal inactivation thermodynamics of milk clotting enzyme from Bacillus subtilis MTCC 10422. LWT - Food Science and Technology, 65, 652-660. http://doi.org/10.1016/j.lwt.2015.08.065

Merheb-Dini, C., Gomes, E., Boscolo, M., \& Silva, R. da. (2010). Production and characterization of a milk-clotting protease in the crude enzymatic extract from the newly isolated Thermomucor indicae-seudaticae N31 ( Milk-clotting protease from the newly isolated. Food Chemistry, 120(1), 87-93. http://doi.org/10.1016/j.foodchem.2009.09.075

Nouani, A., Mati, F. M.-, Belbraouet, S., \& Bellal, M. M. (2011). Purification and characterization of a milk-clotting protease from Mucor pusillus: Method comparison. Journal of Biotechnology, 10(9), 1655-1665. http://doi.org/10.5897/AJB10.1665

Ramachandran, N., \& Arutselvi, R. (2013). Partial purification and characterization of protease enzyme from Nomurarea Rileyi. International Journal of Pharmaceutical Science and Research, 4(9), 3460-3465. http://doi.org/10.13040/IJPSR.0975-8232.4(9).3460-65

Salehi, M., Aghamaalia, M. R., Sajedib, R. H., Asgharia, S. M., \& Jorjani, E. (2017). Purification and characterization of a milk-clotting aspartic protease from Withania coagulans fruit. International Journal of Biological Macromolecules, $98,847-854$

Shieh, C.-J., Thib, L.-A. P., \& Shih, I.-L. (2009). Milk-clotting enzymes produced by culture of Bacillus subtilis natto. Biochemical Engineering Journal, 43, 85-91. http://doi.org/10.1016/j.bej.2008.09.003

Sousa M.J.; Ardo Y.; and McSweeney P.L.H. (2001). Advances in the study of proteolysis during cheese ripening. International Dairy Journal, 11(327-345),
327-345.

Walker, J. M. (2002). The Bicinchoninic Acid (BCA) Assay for Protein Quantitation. In Protein protocol Handbook (2nd editio, pp. 11-15). Humana Press Inc., Totowa, NJ.

Wehaidya, H. R., Abdel-Nabya, M. A., Shoushab, W. G., Mallahb, M. I. Y. El, \& Shawky, M. M. (2016). Optimization of the production and characterization of milk- clotting enzyme from Bacillus subtilis isolated from marine sponge. Egyptian Pharmaceutical Journal, 15, 158-166. http://doi.org/10.4103/1687$\underline{4315.197584}$

Wu, F.-C., Chang, C.-W., \& Shih, I.-L. (2013). Optimization of the production and characterization of milk clotting enzymes by Bacillus subtilis natto. SpringerPlus, 2(33), 2-10.

Yegin;, S., Goksungur;, Y., \& Fernandez-Lahore;, M. (2012). Purification, structural characterization , and technological properties of an aspartyl proteinase from submerged cultures of Mucor mucedo DSM 809. Food Chemistry, 133(4), 1312-1319. http://doi.org/10.1016/j.foodchem.2012.01.075 